Check for updates

Cite this: RSC Adv., 2018, 8, 8678

Received 20th November 2017 Accepted 12th February 2018

DOI: $10.1039 / \mathrm{c} 7 \mathrm{ra} 12610 \mathrm{~g}$

rsc.li/rsc-advances

\section{Fe-Mn bimetallic oxides-catalyzed oxygen reduction reaction in alkaline direct methanol fuel cells}

\author{
Yuan Fang, (D) ${ }^{a}$ Yonghui Wang, ${ }^{a}$ Fen Wang, ${ }^{\text {*a }}$ Chengyong Shu, ${ }^{\mathrm{b}}$ Jianfeng Zhu ${ }^{\mathrm{a}}$ \\ and Wenling $\mathrm{Wu}^{\mathrm{a}}$
}

Two Fe-Mn bimetallic oxides were synthesized through a facile solvothermal method without using any templates. $\mathrm{Fe}_{2} \mathrm{O}_{3} / \mathrm{Mn}_{2} \mathrm{O}_{3}$ is made up of $\mathrm{Fe}_{2} \mathrm{O}_{3}$ and $\mathrm{Mn}_{2} \mathrm{O}_{3}$ as confirmed via XRD. TEM and HRTEM observations show $\mathrm{Fe}_{2} \mathrm{O}_{3}$ nanoparticles uniformly dispersed on the $\mathrm{Mn}_{2} \mathrm{O}_{3}$ substrate and a distinct heterojunction boundary between $\mathrm{Fe}_{2} \mathrm{O}_{3}$ nanoparticles and $\mathrm{Mn}_{2} \mathrm{O}_{3}$ substrate. $\mathrm{MnFe}_{2} \mathrm{O}_{4}$ as a pure phase sample was also prepared and investigated in this study. The current densities in CV tests were normalized to their corresponding surface area to exclude the effect of their specific surface area. Direct methanol fuel cells (DMFCs) were equipped with bimetallic oxides as cathode catalyst, PtRu/C as the anode catalyst and PFM as the electrolyte film. CV and DMFC tests show that $\mathrm{Fe}_{2} \mathrm{O}_{3} / \mathrm{Mn}_{2} \mathrm{O}_{3}(3: 1)$ exhibits higher oxygen reduction reaction (ORR) activity than $\mathrm{Fe}_{2} \mathrm{O}_{3} / \mathrm{Mn}_{2} \mathrm{O}_{3}(1: 1), \mathrm{Fe}_{2} \mathrm{O}_{3} / \mathrm{Mn}_{2} \mathrm{O}_{3}(1: 3), \mathrm{Fe}_{2} \mathrm{O}_{3} /$ $\mathrm{Mn}_{2} \mathrm{O}_{3}(5: 1)$ and $\mathrm{MnFe}_{2} \mathrm{O}_{4}$. The much superior catalytic performance is due to its larger surface area, the existence of numerous heterojunction interfaces and the synergistic effect between $\mathrm{Fe}_{2} \mathrm{O}_{3}$ and $\mathrm{Mn}_{2} \mathrm{O}_{3}$, which can provide numerous catalytic active sites, accelerate mass transfer, and increase ORR efficiency.

\section{Introduction}

The rapid depletion of fossil fuel and the increase in environmental pollution have driven us to search for sustainable and clean energy resources. Fuel cells have been considered promising power sources owing to their advantage of transforming chemical energy directly into electrical energy. ${ }^{1}$ At present, direct methanol fuel cells (DMFCs) are obtaining great attention in virtue of their high energy density, environment friendliness and comparatively lower operating temperature. ${ }^{2-5}$ Furthermore, methanol is convenient and safe for transport and storage, swift to refuel and available at a low price. ${ }^{6}$ At present, DMFCs have great potential application as a portable power supply or electric vehicle power supply. Nevertheless, the inertial oxygen reduction reaction (ORR) and methanol oxidation reaction (MOR) dynamics and the high cost of noble-based catalysts and proton exchange membrane (PEM) hinder the commercial application of DMFCs. ${ }^{4,7,8}$

Recently, polymer fiber membranes (PFMs) have been demonstrated to be an excellent alternative to PEMs for higher performance liquid fuel cells at a reduced cost in our previous study. ${ }^{\mathbf{9} 10}$ The fibers in PFMs are neutral and possess pores and gaps, which allow molecules, ions, and liquid fuel to transport

${ }^{a}$ School of Materials Science and Engineering, Shaanxi University of Science and Technology, Xi'an 710021, P. R. China.E-mail: wangf@sust.edu.cn

${ }^{b}$ State Key Laboratory for Mechanical Behavior of Materials, Xi'an Jiaotong University, Xi'an 710049, P. R. China or move through the PFM freely. Consequently, the cathode catalysts should have both outstanding tolerance for methanol poisoning and excellent stability. The widely used cathode catalysts are Pt or Pt-based metal alloy catalysts, such as Pt-Co, ${ }^{11}$ Pt-Pd, ${ }^{4} \mathrm{Pt}-\mathrm{Ni},{ }^{12}$ and Pt-Fe. ${ }^{13}$ However, these catalysts have both ORR and MOR catalytic activity, leading to a mixed potential at the cathode and poisoning by methanol. In terms of lower cost, a variety of non-Pt catalysts, such as $\mathrm{Ru}-\mathrm{Se},{ }^{14} \mathrm{Pd}-\mathrm{Ni},{ }^{15} \mathrm{Pd}-\mathrm{Fe},{ }^{16}$ $\mathrm{Co}-\mathrm{Se},{ }^{17} \mathrm{Fe}-\mathrm{N}-\mathrm{C},{ }^{18} \mathrm{Cu}-\mathrm{Fe}-\mathrm{S},{ }^{19}$ and $\mathrm{Co}-\mathrm{O},{ }^{20}$ which display ORR catalytic activity and better methanol tolerance than Pt-based catalysts, also have been researched.

Among them, transition metal (Fe, Co, Ni, Mn, etc.) oxides have gained increasing interest as ORR catalysts in virtue of their high activity, low cost and environmental friendliness. ${ }^{21}$ In recent years, numerous studies have focused on binary and ternary metal oxides because of their good synergistic effects and good cycle stability. $\mathrm{NiCo}_{2} \mathrm{O}_{4},{ }^{22} \mathrm{KMn}_{8} \mathrm{O}_{16},{ }^{23} \mathrm{MnFe}_{2} \mathrm{O}_{4},{ }^{24}$ and Co-Ni-Te- ${ }^{25}$ have higher ORR catalytic activities and methanol tolerance. For example, the catalytic activity of $\mathrm{MnFe}_{2} \mathrm{O}_{4}$ is higher than that of $\mathrm{Fe}_{2} \mathrm{O}_{3}$ (ref. 26) and $\mathrm{Mn}_{2} \mathrm{O}_{3} \cdot{ }^{27}$ Nevertheless, the catalytic activity of the mixed compound of $\mathrm{Fe}_{2} \mathrm{O}_{3}$ and $\mathrm{Mn}_{2} \mathrm{O}_{3}$ has not been discussed.

In this study, we prepared two Fe-Mn bimetallic oxides, namely, $\mathrm{Fe}_{2} \mathrm{O}_{3} / \mathrm{Mn}_{2} \mathrm{O}_{3}$ and $\mathrm{MnFe}_{2} \mathrm{O}_{4}$ by a simple solvothermal method. $\mathrm{Fe}_{2} \mathrm{O}_{3} / \mathrm{Mn}_{2} \mathrm{O}_{3}$ is made up of $\mathrm{Fe}_{2} \mathrm{O}_{3}$ and $\mathrm{Mn}_{2} \mathrm{O}_{3}$ as confirmed via XRD. $\mathrm{MnFe}_{2} \mathrm{O}_{4}$ is a pure phase sample. The asprepared $\mathrm{Fe}_{2} \mathrm{O}_{3} / \mathrm{Mn}_{2} \mathrm{O}_{3}$ exists in the form of porous nanosheets-self-assembled globular structure. The 
microspheres are $3-4 \mu \mathrm{m}$ in diameter and the pore size is about $30 \mathrm{~nm}$. The TEM and HRTEM images show $\mathrm{Fe}_{2} \mathrm{O}_{3}$ nanoparticles uniformly dispersed on the $\mathrm{Mn}_{2} \mathrm{O}_{3}$ substrate and a distinct heterojunction boundary between $\mathrm{Fe}_{2} \mathrm{O}_{3}$ nanoparticles and $\mathrm{Mn}_{2} \mathrm{O}_{3}$ substrate. $\mathrm{MnFe}_{2} \mathrm{O}_{4}$ has a hierarchical structure, in which the nanoparticles are $20-30 \mathrm{~nm}$ in diameter and create self-assembled globular shapes with diameters of 300-500 nm. The alkaline DMFCs were assembled using $\mathrm{Fe}_{2} \mathrm{O}_{3} / \mathrm{Mn}_{2} \mathrm{O}_{3}$ or $\mathrm{MnFe}_{2} \mathrm{O}_{4}$ as cathode catalyst, PtRu/C as anode catalyst, and PFM instead of PEM. CV and DMFC performance tests indicate that the ORR catalytic activity of $\mathrm{Fe}_{2} \mathrm{O}_{3} / \mathrm{Mn}_{2} \mathrm{O}_{3}$ is superior to that of $\mathrm{MnFe}_{2} \mathrm{O}_{4}$.

\section{Experimental section}

\subsection{Synthesis of $\mathrm{Fe}_{2} \mathrm{O}_{3} / \mathrm{Mn}_{2} \mathrm{O}_{3}$ and $\mathrm{MnFe}_{2} \mathrm{O}_{4}$ catalysts}

All reagents were analytical grade and used without further purification. All the reagents were purchased from Sinopharm Chemical Reagent Co. Ltd. The anode catalyst PtRu/C (HiSpec 3000) was bought from Johnson Matthey (UK). Multiwalled carbon nanotubes (TNM7, >95\%, OD: 30-50 nm, length: 10-20 $\mathrm{mm}$ ) were obtained from Chengdu Organic Chemicals Co. Ltd (Chengdu, China). They were produced by natural gas catalytic decomposition over a nickel-based catalyst and purified with dilute hydrochloric acid at $80{ }^{\circ} \mathrm{C}$. The PFM (thickness $1 / 4159.3$ $\mu \mathrm{m})$ was purchased from the Nippon Kodoshi Corporation.

In the synthesis of $\mathrm{Fe}_{2} \mathrm{O}_{3} / \mathrm{Mn}_{2} \mathrm{O}_{3}$, first, $25 \mathrm{~mL}$ ethylene glycol (EG) and $0.14 \mathrm{~g}$ Tween 80 were dissolved into $25 \mathrm{~mL}$ ultrapure water to form a transparent solution. Then, $3 \mathrm{mmol} \mathrm{MnSO}_{4}$ $\cdot \mathrm{H}_{2} \mathrm{O}, 9 \mathrm{mmol} \mathrm{Fe}\left(\mathrm{NO}_{3}\right)_{3} \cdot 9 \mathrm{H}_{2} \mathrm{O}$ and $30 \mathrm{mmol}$ urea were added to the solution, which was then magnetically stirred at $25{ }^{\circ} \mathrm{C}$ for $1 \mathrm{~h}$, forming a red-brown solution. Next, the solution was put into a $100 \mathrm{~mL}$ Teflon-lined stainless-steel autoclave, which was then heated at $200{ }^{\circ} \mathrm{C}$ for $24 \mathrm{~h}$ with continuous rotation. The precipitate was washed by centrifugation with anhydrous ethanol and ultrapure water several times until the $\mathrm{pH}$ was 7 and the precursor of $\mathrm{Fe}_{2} \mathrm{O}_{3} / \mathrm{Mn}_{2} \mathrm{O}_{3}$ was obtained by drying it at $80{ }^{\circ} \mathrm{C}$ for $12 \mathrm{~h}$. The resultant product was calcined at $800{ }^{\circ} \mathrm{C}$ in air for $5 \mathrm{~h}$ in a muffle furnace to obtain the $\mathrm{Fe}_{2} \mathrm{O}_{3} / \mathrm{Mn}_{2} \mathrm{O}_{3}$ sample. $\mathrm{Fe}_{2} \mathrm{O}_{3} / \mathrm{Mn}_{2} \mathrm{O}_{3}$ with different Fe/Mn ratios of $1: 1,1: 3$, $3: 1$ and $5: 1$ were prepared for comparison, which were controlled by altering the molar ratio of $\mathrm{MnSO}_{4} \cdot \mathrm{H}_{2} \mathrm{O}$ and $\mathrm{Fe}\left(\mathrm{NO}_{3}\right)_{3} \cdot 9 \mathrm{H}_{2} \mathrm{O}$. The samples were designated as $\mathrm{Fe}_{2} \mathrm{O}_{3} /$ $\mathrm{Mn}_{2} \mathrm{O}_{3}(1: 1), \quad \mathrm{Fe}_{2} \mathrm{O}_{3} / \mathrm{Mn}_{2} \mathrm{O}_{3}(1: 3), \quad \mathrm{Fe}_{2} \mathrm{O}_{3} / \mathrm{Mn}_{2} \mathrm{O}_{3}(3: 1)$ and $\mathrm{Fe}_{2} \mathrm{O}_{3} / \mathrm{Mn}_{2} \mathrm{O}_{3}(5: 1)$, respectively.

The precursor of $\mathrm{MnFe}_{2} \mathrm{O}_{4}$ was synthesized following the same solvothermal method except the raw materials were $2.5 \mathrm{mmol} \mathrm{Mn}\left(\mathrm{CH}_{3} \mathrm{COO}\right)_{2} \cdot 4 \mathrm{H}_{2} \mathrm{O}$, $5.0 \mathrm{mmol} \mathrm{FeCl}_{3} \cdot 6 \mathrm{H}_{2} \mathrm{O}, 1.0 \mathrm{~g}$ polyethylene glycol (PEG), $3.6 \mathrm{~g} \mathrm{CH}_{3} \mathrm{COONa}$ and $40 \mathrm{~mL}$ ethylene glycol (EG). The $\mathrm{MnFe}_{2} \mathrm{O}_{4}$ catalyst sample was obtained after calcination at $500{ }^{\circ} \mathrm{C}$ in air for $4 \mathrm{~h}$.

\subsection{Materials characterization}

The structures and compositions of the as-prepared $\mathrm{Fe}_{2} \mathrm{O}_{3}$ / $\mathrm{Mn}_{2} \mathrm{O}_{3}$ and $\mathrm{MnFe}_{2} \mathrm{O}_{4}$ were characterized via X-ray diffraction (XRD, D/Max 2200PC, Japan) and high-resolution TEM
(HRTEM). The morphological properties were characterized by field emission scanning electron microscopy (FESEM, Hitachi S4800, Japan) and transmission electron microscopy (TEM, FEI company Tecnai G2 F20) equipped with energy-dispersive spectrometer (EDS). The Brunauer-Emmett-Teller (BET) method was carried out to determine the pore volumes, pore size and the specific surface area distribution of the samples using a surface area and porosimetry system (ASAP 2460, Micromeritics Instrument Corporation, USA). X-ray photoelectron spectroscopy (XPS) measurements (VG Thermo ESCALAB 250 spectrometer) were used to quantitatively analyze the chemical compositions of samples.

\subsection{Electrochemical measurements}

Cyclic voltammetry (CV) and electrochemical impedance spectroscopy (EIS) were measured using an electrochemical workstation (CHI 660E, Chenhua Instruments, Shanghai, China). A standard three-electrode system consisted of the catalystmodified glassy carbon electrode as the working electrode, $\mathrm{Hg} / \mathrm{HgO}$ electrode as the reference electrode and the Pt network as the counter electrode. The glassy carbon electrode was modified as follows: $4 \mathrm{mg}$ catalyst, $1 \mathrm{mg}$ CNTs, $0.2 \mathrm{~mL}$ distilled water, $0.5 \mathrm{~mL}$ absolute ethyl alcohol and $50 \mu \mathrm{L}$ Nafion solution (5 wt\%) were ultrasonically dispersed into a homogeneous suspension for about $1 \mathrm{~h}$; then, the suspension was poured on the glassy carbon electrode surface and dried at room temperature.

\subsection{Electrode preparation and DMFC measurements}

The cathode electrode was a sandwich structure, including catalyst layer, current accumulating matrix and gas diffusion layer. The gas diffusion layer was obtained by mixing $60 \mathrm{wt} \%$ acetylene black and $40 \mathrm{wt} \%$ polytetrafluoroethylene (PTFE, $30 \mathrm{wt} \%$ solution) with ethanol under ultrasonication and pressing the slurry into a thin layer of $0.3-0.5 \mathrm{~mm}$ and then treating at $350{ }^{\circ} \mathrm{C}$ for $1 \mathrm{~h}$. The catalyst layer was obtained first through mixing $24 \mathrm{mg}$ catalyst, $6 \mathrm{mg}$ CNTs and $6.7 \mathrm{mg} 30 \mathrm{wt} \%$ PTFE solution into slurry with addition of a certain amount of absolute ethanol; the slurry was pasted on nickel foam (porosity $>95 \%$ ) and then dried at $80^{\circ} \mathrm{C}$ for $2 \mathrm{~h}$. Finally, the cathode was obtained by pressing the catalyst layer on nickel foam and the gas diffusion layer under $2 \mathrm{MPa}$.

The anode was obtained via mixing PtRu/C (60 wt\%) and Nafion solution $(5 \mathrm{wt} \%)$ at a mass ratio of $1: 1$. The anode preparation process is consistent with that of the cathode without the gas diffusion layer. The loading of PtRu/C was $5 \mathrm{mg} \mathrm{cm}^{-2}$.

The cathode, PFM and anode were assembled into a fuel cell. At the cathode, the oxygen flow rate was 20 cubic centimeters per minute; the anode aqueous solution was $4 \mathrm{M} \mathrm{KOH}$ and $5 \mathrm{M}$ methanol. The structure of PFM-DMFCs was introduced and described in our previous study. ${ }^{9}$ A battery testing system (Neware Technology Co., Ltd., Shenzhen, China) was used to measure the performance. 

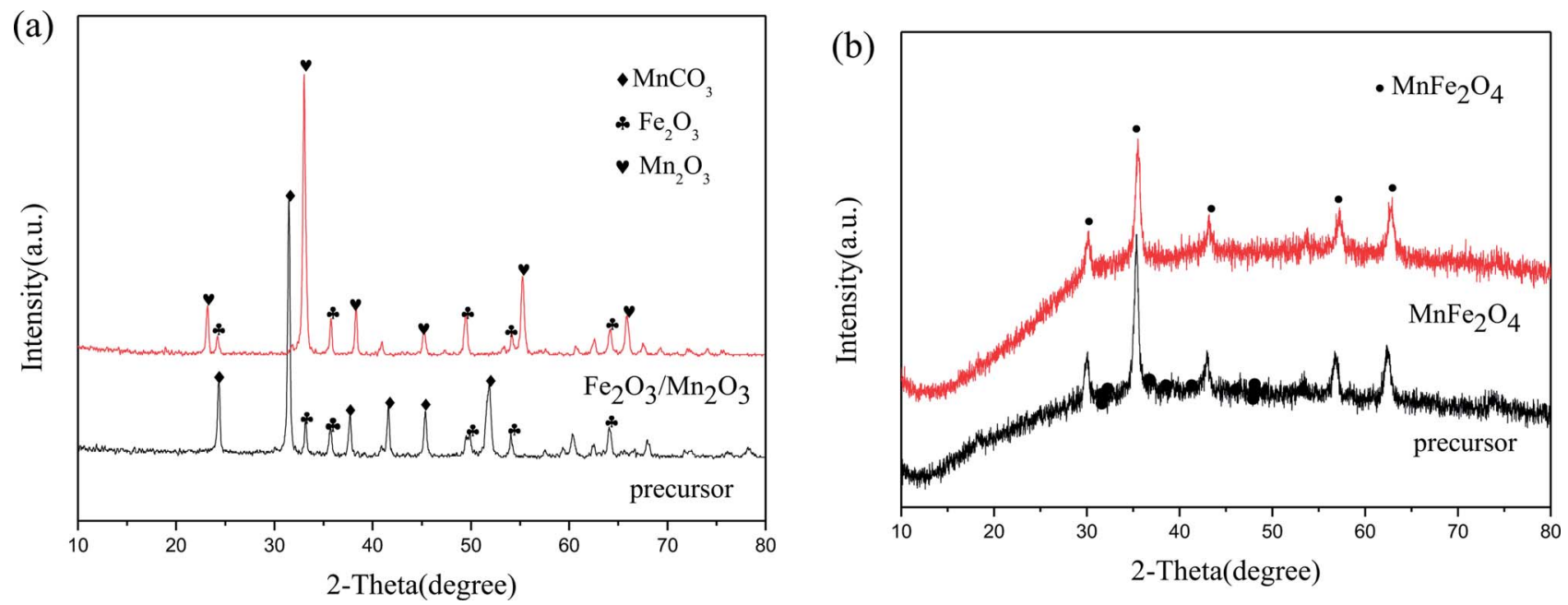

Fig. 1 XRD patterns of (a) $\mathrm{Fe}_{2} \mathrm{O}_{3} / \mathrm{Mn}_{2} \mathrm{O}_{3}(3: 1)$ and its precursor; (b) $\mathrm{MnFe}_{2} \mathrm{O}_{4}$ and its precursor.

\section{Results and discussion}

\subsection{Structural and morphological characterization}

Fig. 1 displays the XRD patterns of $\mathrm{Fe}_{2} \mathrm{O}_{3} / \mathrm{Mn}_{2} \mathrm{O}_{3}(3: 1)$, $\mathrm{MnFe}_{2} \mathrm{O}_{4}$ and their precursors. The precursor of $\mathrm{Fe}_{2} \mathrm{O}_{3} /$ $\mathrm{Mn}_{2} \mathrm{O}_{3}(3: 1)$ can be well indexed to $\mathrm{Fe}_{2} \mathrm{O}_{3}$ (JCPDS no. 33-0664) and $\mathrm{MnCO}_{3}$ (JCPDS no. 44-1472). However, the diffraction peaks of $\mathrm{Fe}_{2} \mathrm{O}_{3} / \mathrm{Mn}_{2} \mathrm{O}_{3}(3: 1)$ agree with the standard patterns of $\mathrm{Fe}_{2} \mathrm{O}_{3}$ (JCPDS no. 33-0664) and $\mathrm{Mn}_{2} \mathrm{O}_{3}$ (JCPDS no. 24-0508). It can be illustrated that $\mathrm{Fe}_{2} \mathrm{O}_{3} / \mathrm{Mn}_{2} \mathrm{O}_{3}(3: 1)$ is composed of $\mathrm{Mn}_{2} \mathrm{O}_{3}$ and $\mathrm{Fe}_{2} \mathrm{O}_{3}$ and the formation of $\mathrm{Mn}_{2} \mathrm{O}_{3}$ is due to the decomposition of $\mathrm{MnCO}_{3}$ in its precursor. Moreover, the diffraction peaks of $\mathrm{MnFe}_{2} \mathrm{O}_{4}$ and its precursor can be well assigned to the standard patterns of $\mathrm{MnFe}_{2} \mathrm{O}_{4}$ (JCPDS no. 10-0319).

FESEM was applied to describe the morphology of $\mathrm{Fe}_{2} \mathrm{O}_{3}$ / $\mathrm{Mn}_{2} \mathrm{O}_{3}(3: 1), \mathrm{MnFe}_{2} \mathrm{O}_{4}$ and their precursors. Fig. 2(a) shows that the precursor of $\mathrm{Fe}_{2} \mathrm{O}_{3} / \mathrm{Mn}_{2} \mathrm{O}_{3}(3: 1)$ exhibits two morphologies, which are nanoparticles and nanostructured bulk, while the $\mathrm{Fe}_{2} \mathrm{O}_{3} / \mathrm{Mn}_{2} \mathrm{O}_{3}(3: 1)$ catalyst exists as sub-sized porous nanosheets-self-assembled globular structure (Fig. 2(b)). The microspheres of $\mathrm{Fe}_{2} \mathrm{O}_{3} / \mathrm{Mn}_{2} \mathrm{O}_{3}(3: 1)$ are 3-4 $\mu \mathrm{m}$ in diameter and the pore size is about $30 \mathrm{~nm}$. From the XRD analysis results shown in Fig. 1(a), it can be inferred that the formation of nanopores is due to the release of $\mathrm{CO}_{2}$, which comes from $\mathrm{MnCO}_{3}$ decomposition during the calcination process. In particular, mesoporous structure is profitable for the rapid transmission of $\mathrm{O}_{2}$, fuel and electrolyte, which can accelerate the redox reaction rate and improve electrochemical performance. ${ }^{28}$ Further, the EDS elemental mappings of $\mathrm{Fe}_{2} \mathrm{O}_{3} /$ $\mathrm{Mn}_{2} \mathrm{O}_{3}(3: 1)$ (Fig. 2(c)-(f)) were recorded to obtain elemental distribution of $\mathrm{Fe}, \mathrm{Mn}$ and $\mathrm{O}$ in the structure and it could be observed that the three elements are distributed homogeneously. As shown in Fig. 3(a) and (b), $\mathrm{MnFe}_{2} \mathrm{O}_{4}$ catalyst and its precursor have similar hierarchical structures. The nanoparticles are $20-30 \mathrm{~nm}$ in diameter and exhibit self-assembled globular shapes with diameters of 300-500 $\mathrm{nm}$. Moreover, the
EDS elemental mapping of $\mathrm{MnFe}_{2} \mathrm{O}_{4}$ clearly indicates that the Fe, Mn and $\mathrm{O}$ elements are uniformly distributed (Fig. 3(c)-(f)).

The TEM image of $\mathrm{Fe}_{2} \mathrm{O}_{3} / \mathrm{Mn}_{2} \mathrm{O}_{3}(3: 1)$ (Fig. 4(a)) shows that numerous nanoparticles with diameters of $10-30 \mathrm{~nm}$ are uniformly dispersed on the substrate. To better characterize the microstructure, a HRTEM image of $\mathrm{Fe}_{2} \mathrm{O}_{3} / \mathrm{Mn}_{2} \mathrm{O}_{3}(3: 1)$ was obtained (Fig. 4(b)). The nanoparticle has a clear lattice fringe with $d$-spacing of $0.37 \mathrm{~nm}$ and $0.22 \mathrm{~nm}$, corresponding to the $\mathrm{Fe}_{2} \mathrm{O}_{3}$ phase (104) and (113) plane, respectively, while that of the substrate is $0.38 \mathrm{~nm}$ and $0.31 \mathrm{~nm}$, corresponding to the (211) and (122) plane of $\mathrm{Mn}_{2} \mathrm{O}_{3}$, respectively. Therefore, $\mathrm{Fe}_{2} \mathrm{O}_{3}$ / $\mathrm{Mn}_{2} \mathrm{O}_{3}(3: 1)$ consists of $\mathrm{Fe}_{2} \mathrm{O}_{3}$ and $\mathrm{Mn}_{2} \mathrm{O}_{3}$, which is consistent with the XRD results. As shown in Fig. 4(b), a distinct heterojunction boundary between $\mathrm{Fe}_{2} \mathrm{O}_{3}$ nanoparticles and $\mathrm{Mn}_{2} \mathrm{O}_{3}$ substrate could be detected as shown by the red line. Fig. 4(c) shows that $\mathrm{MnFe}_{2} \mathrm{O}_{4}$ exists as nanospheres with diameters of $300-500 \mathrm{~nm}$. The lattice fringe with $d$-spacing is $0.25 \mathrm{~nm}$, which can be well indexed to the (311) plane of $\mathrm{MnFe}_{2} \mathrm{O}_{4}$ phase (Fig. 4(d)).

XPS was used to measure the surface chemical composition and confirm the Fe/Mn ratio of the as-prepared $\mathrm{Fe}_{2} \mathrm{O}_{3} / \mathrm{Mn}_{2} \mathrm{O}_{3}$ samples. As shown in Fig. 5(a), the common peaks of Fe 2p, Mn $2 \mathrm{p}$ and $\mathrm{O} 1 \mathrm{~s}$ are present. The element contents are calculated and summarized in Table 1, illustrating that the results of Fe/ $\mathrm{Mn}$ ratios are approximately equal to the corresponding experimental values. The $\mathrm{N}_{2}$ adsorption-desorption technique at $77 \mathrm{~K}$ was used to investigate specific surface areas and pore structures of the as-prepared samples. The nitrogen adsorptiondesorption curves (Fig. 5(b)) manifest a type IV isothermal line with a delay loop-line in the $P / P_{0}$ range of 0.9-1.0 for $\mathrm{Fe}_{2} \mathrm{O}_{3} /$ $\mathrm{Mn}_{2} \mathrm{O}_{3}$ samples and 0.8-1.0 for $\mathrm{MnFe}_{2} \mathrm{O}_{4}$, indicating porous structures. The BET surface areas are 12.390, 19.889, 21.73 and $18.165 \mathrm{~m}^{2} \mathrm{~g}^{-1}$ for $\mathrm{Fe}_{2} \mathrm{O}_{3} / \mathrm{Mn}_{2} \mathrm{O}_{3}(1: 1), \mathrm{Fe}_{2} \mathrm{O}_{3} / \mathrm{Mn}_{2} \mathrm{O}_{3}(1: 3)$, $\mathrm{Fe}_{2} \mathrm{O}_{3} / \mathrm{Mn}_{2} \mathrm{O}_{3}(3: 1)$ and $\mathrm{Fe}_{2} \mathrm{O}_{3} / \mathrm{Mn}_{2} \mathrm{O}_{3}(5: 1)$, while their pore sizes are 55.7, 32.8, 32.8, and $43.7 \mathrm{~nm}$, respectively. $\mathrm{MnFe}_{2} \mathrm{O}_{4}$ illustrates the BET surface area and pore size of $3.05 \mathrm{~m}^{2} \mathrm{~g}^{-1}$ and $14.4 \mathrm{~nm}$, respectively. 

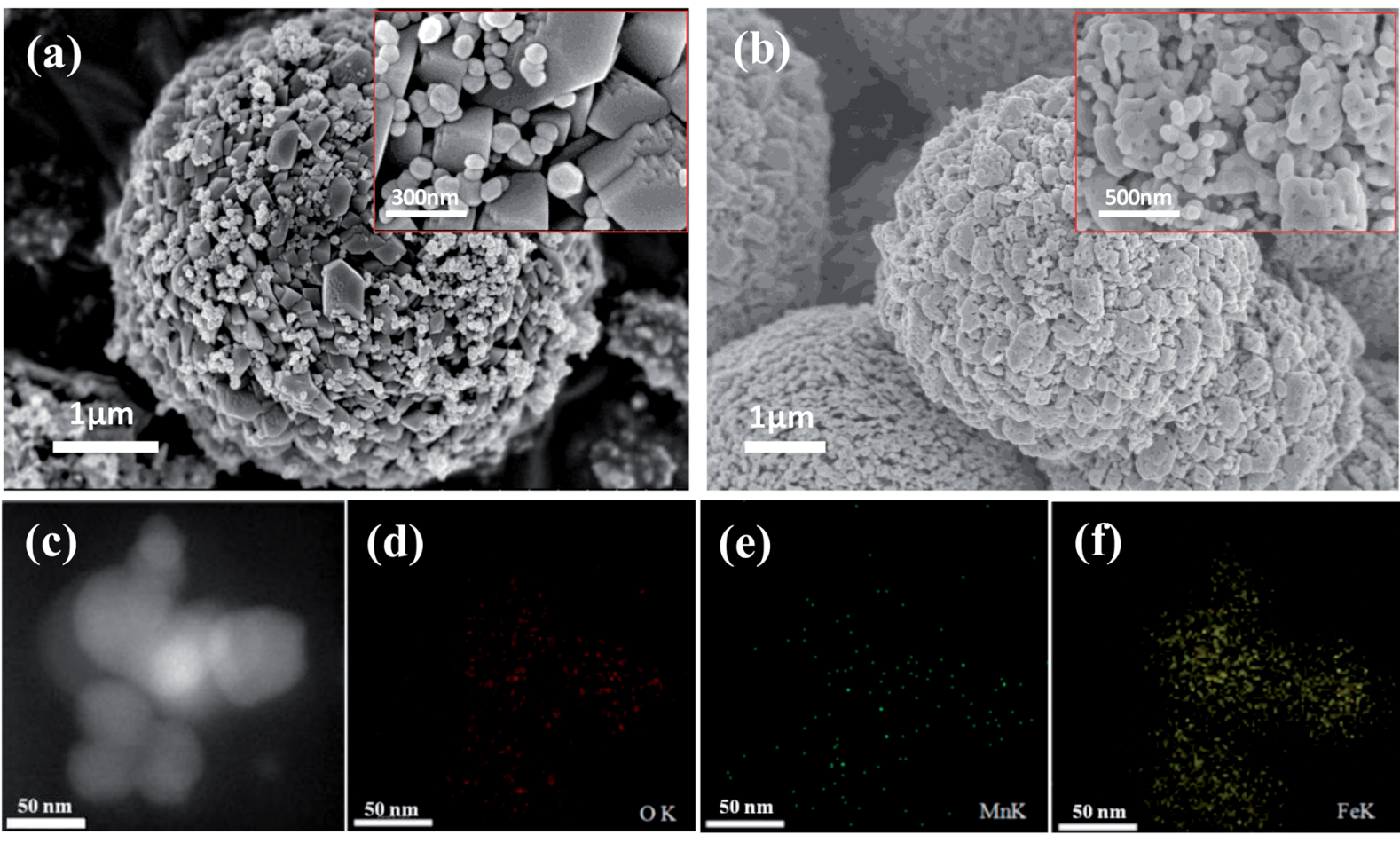

Fig. 2 FESEM images of (a) the precursor of $\mathrm{Fe}_{2} \mathrm{O}_{3} / \mathrm{Mn}_{2} \mathrm{O}_{3}(3: 1)$ and (b) $\mathrm{Fe}_{2} \mathrm{O}_{3} / \mathrm{Mn}_{2} \mathrm{O}_{3}(3: 1)$; EDS elemental mapping images of Fe $\mathrm{O}_{3} / \mathrm{Mn}_{2} \mathrm{O}_{3}((\mathrm{c})$ to $(f)$ ).

\subsection{ORR activity and DMFC performance}

$\mathrm{CV}$ tests were performed to describe ORR catalytic activity. The current densities were normalized to their corresponding surface area. Capacitance correction was acquired by subtracting the measured current densities under $\mathrm{N}_{2}$ from those measured under $\mathrm{O}_{2}$ under the same condition. Fig. 6(a) shows the $\mathrm{CV}$ curves of $\mathrm{Fe}_{2} \mathrm{O}_{3} / \mathrm{Mn}_{2} \mathrm{O}_{3}$ with different $\mathrm{Fe} / \mathrm{Mn}$ ratios and $\mathrm{MnFe}_{2} \mathrm{O}_{4}$ modified glassy carbon electrodes in $\mathrm{O}_{2}$-saturated $1 \mathrm{M} \mathrm{KOH}$ solution. Oxygen reduction peaks of these samples are
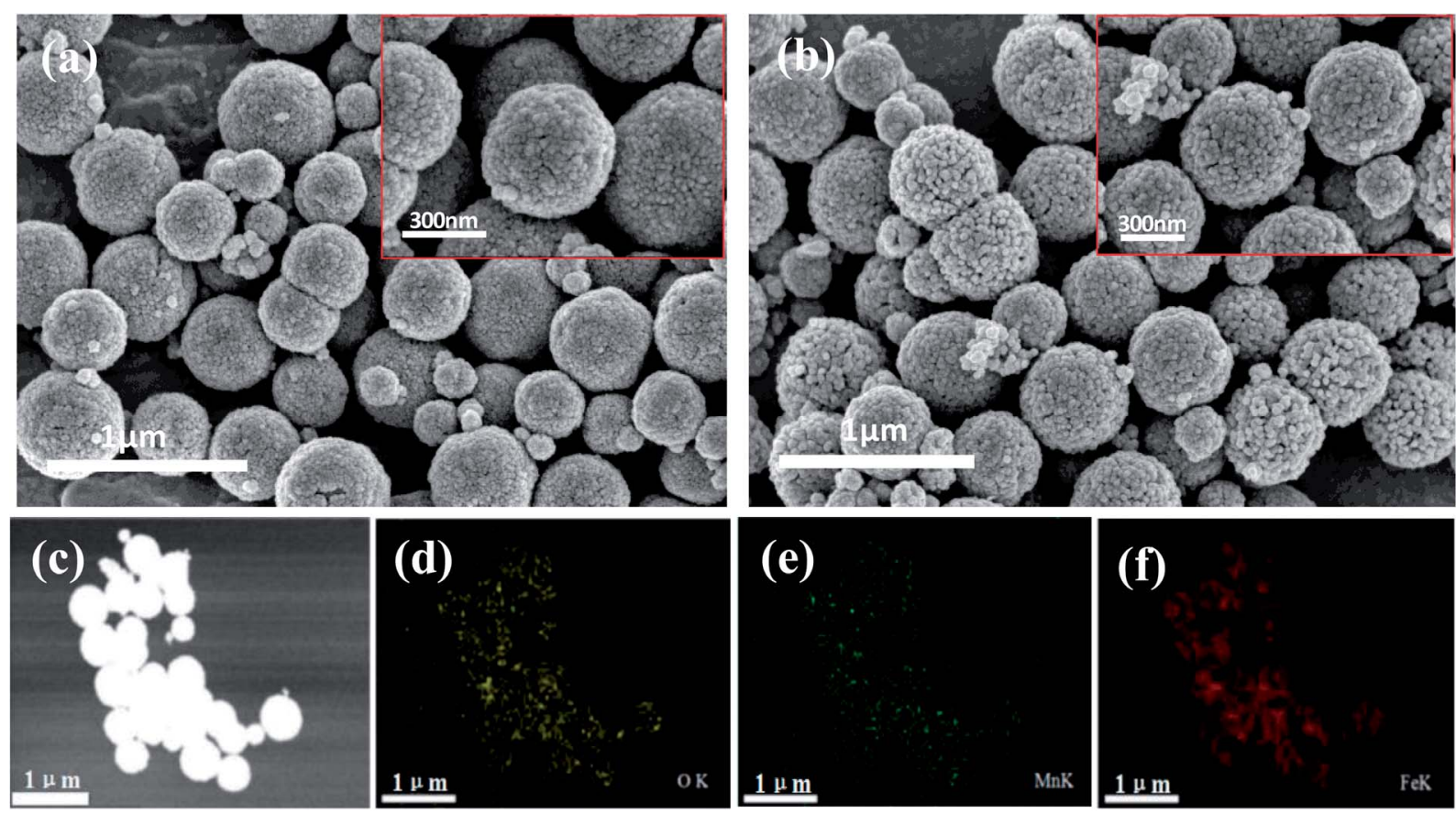

Fig. 3 FESEM images of (a) the precursor of $\mathrm{MnFe}_{2} \mathrm{O}_{4}$ and (b) $\mathrm{MnFe}_{2} \mathrm{O}_{4}$ catalyst; EDS elemental mapping images of $\mathrm{MnFe}_{2} \mathrm{O}_{4}$ catalyst ((c) to (f)). 

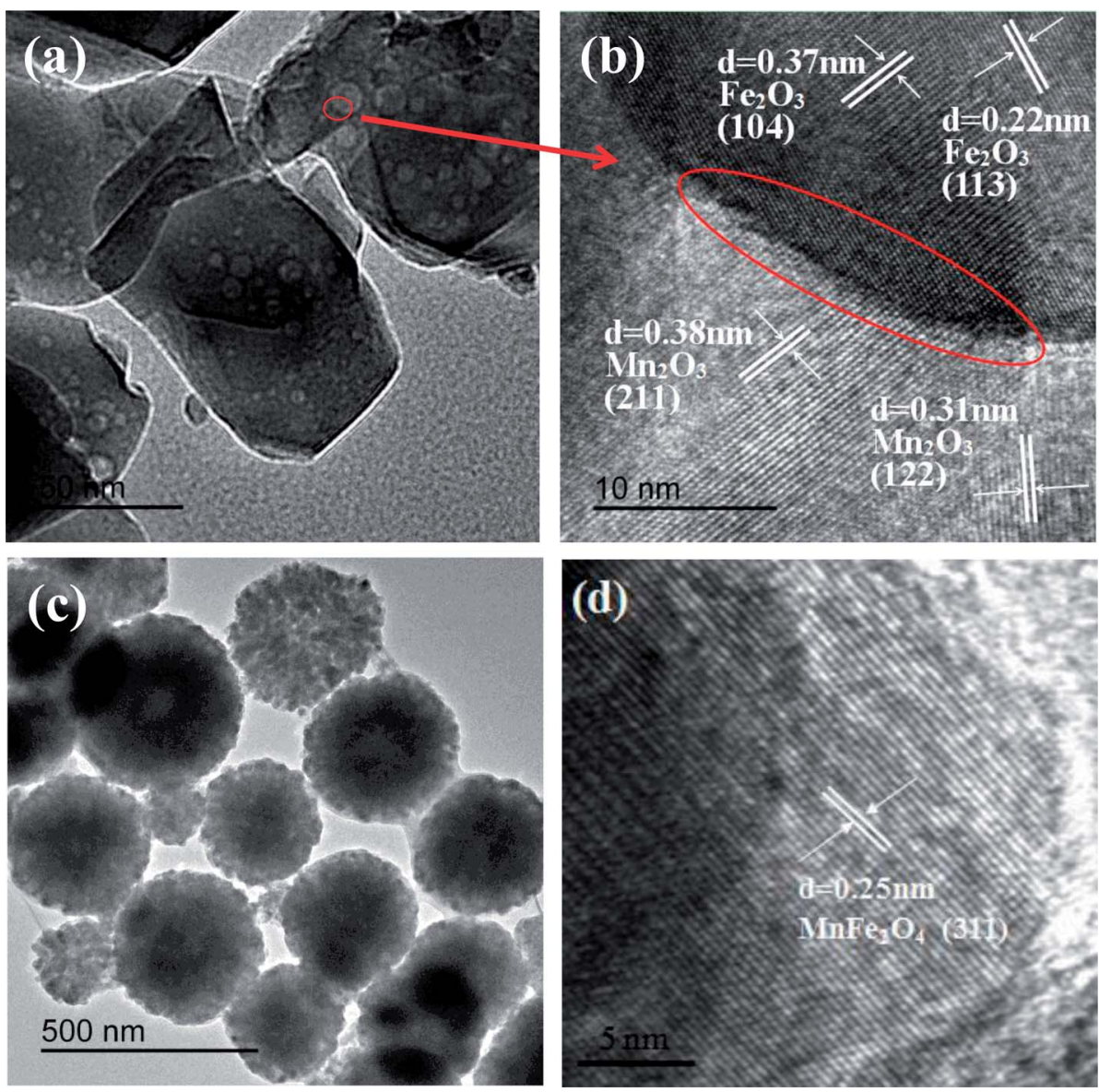

Fig. 4 (a) TEM and (b) HRTEM images of $\mathrm{Fe}_{2} \mathrm{O}_{3} / \mathrm{Mn}_{2} \mathrm{O}_{3}\left(3\right.$ : 1); (c) TEM and (d) HRTEM images of $\mathrm{MnFe}_{2} \mathrm{O}_{4}$.

distinct, demonstrating their ORR catalytic activities. Their oxygen reduction peak current densities and corresponding potentials are summarized in Table 2 . The oxygen reduction peak current densities are $-58.43,-61.21,-86.7$ and $-47.9 \mathrm{~mA}$ $\mathrm{m}^{-2}$ for $\mathrm{Fe}_{2} \mathrm{O}_{3} / \mathrm{Mn}_{2} \mathrm{O}_{3}(1: 1), \quad \mathrm{Fe}_{2} \mathrm{O}_{3} / \mathrm{Mn}_{2} \mathrm{O}_{3}(1: 3), \quad \mathrm{Fe}_{2} \mathrm{O}_{3} /$
$\mathrm{Mn}_{2} \mathrm{O}_{3}(3: 1)$ and $\mathrm{Fe}_{2} \mathrm{O}_{3} / \mathrm{Mn}_{2} \mathrm{O}_{3}(5: 1)$, respectively, while the corresponding peak potentials are $-0.246,-0.267,-0.348$ and $-0.257 \mathrm{~V}$. Clearly, $\mathrm{Fe}_{2} \mathrm{O}_{3} / \mathrm{Mn}_{2} \mathrm{O}_{3}(3: 1)$ has the highest oxygenreduction peak current density. As compared $\mathrm{MnFe}_{2} \mathrm{O}_{4}$, although the reduction peak potential of $\mathrm{Fe}_{2} \mathrm{O}_{3} / \mathrm{Mn}_{2} \mathrm{O}_{3}(3: 1)$ is
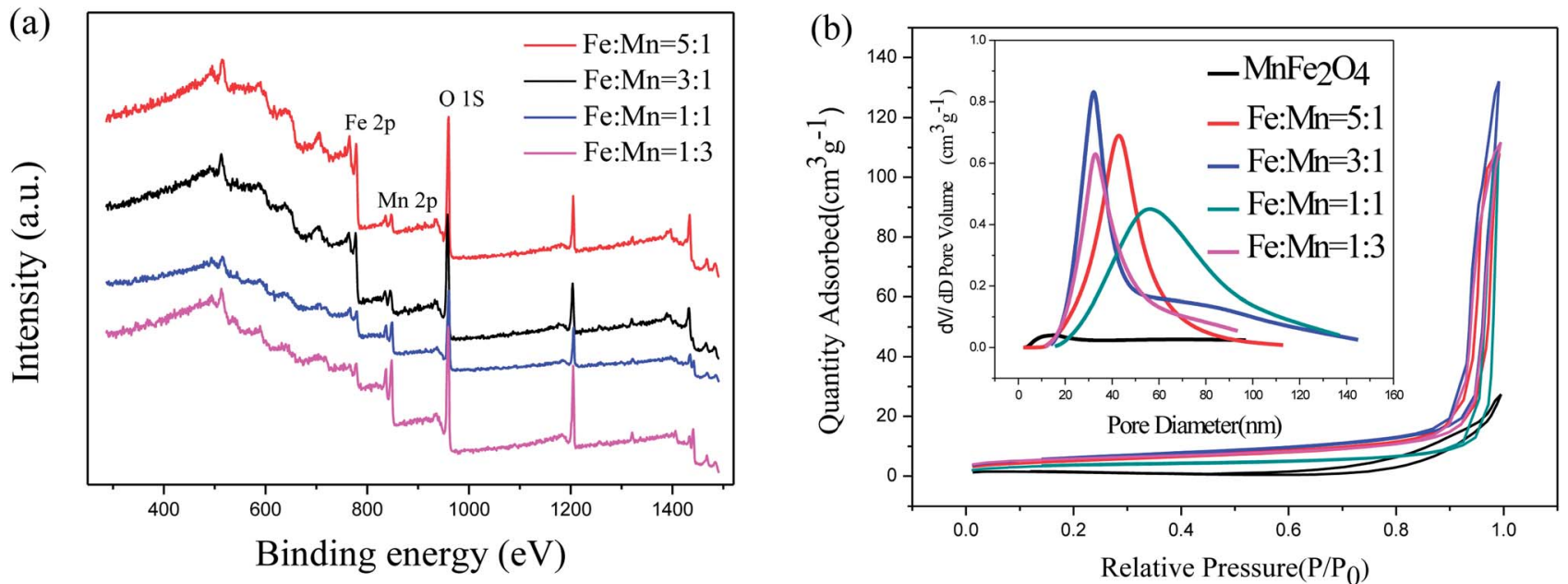

Fig. 5 (a) XPS survey spectra of $\mathrm{Fe}_{2} \mathrm{O}_{3} / \mathrm{Mn}_{2} \mathrm{O}_{3}$ with different Fe/Mn ratios; (b) nitrogen adsorption-desorption isotherms and pore size distributions of $\mathrm{Fe}_{2} \mathrm{O}_{3} / \mathrm{Mn}_{2} \mathrm{O}_{3}$ with different $\mathrm{Fe} / \mathrm{Mn}$ ratios and $\mathrm{MnFe}_{2} \mathrm{O}_{4}$. 
Table 1 Elemental composition of $\mathrm{Fe}_{2} \mathrm{O}_{3} / \mathrm{Mn}_{2} \mathrm{O}_{3}$ with different Fe/Mn ratios

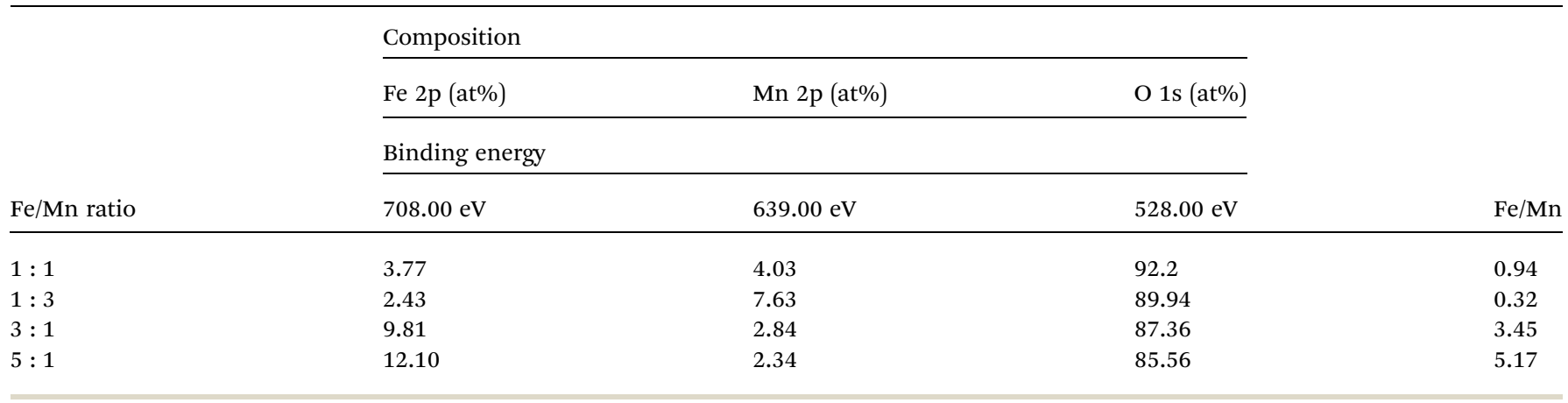

slightly more negative than that of $\mathrm{MnFe}_{2} \mathrm{O}_{4}(-0.237 \mathrm{~V})$, the oxygen-reduction peak current density is much greater than that of $\mathrm{MnFe}_{2} \mathrm{O}_{4}\left(-26.26 \mathrm{~mA} \mathrm{~m}{ }^{-2}\right)$. CV results indicate $\mathrm{Fe}_{2} \mathrm{O}_{3} /$ $\mathrm{Mn}_{2} \mathrm{O}_{3}$ exhibits higher ORR activity than $\mathrm{MnFe}_{2} \mathrm{O}_{4}$, which have excluded the effect of their specific surface area, demonstrating $\mathrm{Fe}_{2} \mathrm{O}_{3} / \mathrm{Mn}_{2} \mathrm{O}_{3}$ has more active sites probably introduced by heterojunction boundary between $\mathrm{Fe}_{2} \mathrm{O}_{3}$ and $\mathrm{Mn}_{2} \mathrm{O}_{3}$.
The polarization and power density curves of $\mathrm{Fe}_{2} \mathrm{O}_{3} / \mathrm{Mn}_{2} \mathrm{O}_{3}$ with different $\mathrm{Fe} / \mathrm{Mn}$ ratios and $\mathrm{MnFe}_{2} \mathrm{O}_{4}$ used as cathode catalysts in DMFCs are shown in Fig. 6(b). The maximum power densities $\left(P_{\max }\right)$ for these catalysts are 17.09, 15.54, 20.29, 12.88 and $12.15 \mathrm{~mW} \mathrm{~cm}{ }^{-2}$ for $\mathrm{Fe}_{2} \mathrm{O}_{3} / \mathrm{Mn}_{2} \mathrm{O}_{3}(1: 1)$, $\mathrm{Fe}_{2} \mathrm{O}_{3} / \mathrm{Mn}_{2} \mathrm{O}_{3}(1: 3), \quad \mathrm{Fe}_{2} \mathrm{O}_{3} / \mathrm{Mn}_{2} \mathrm{O}_{3}(3: 1), \quad \mathrm{Fe}_{2} \mathrm{O}_{3} / \mathrm{Mn}_{2} \mathrm{O}_{3}(5: 1)$ and $\mathrm{MnFe}_{2} \mathrm{O}_{4}$, respectively. These data indicate that the $\mathrm{Fe}_{2} \mathrm{O}_{3} /$
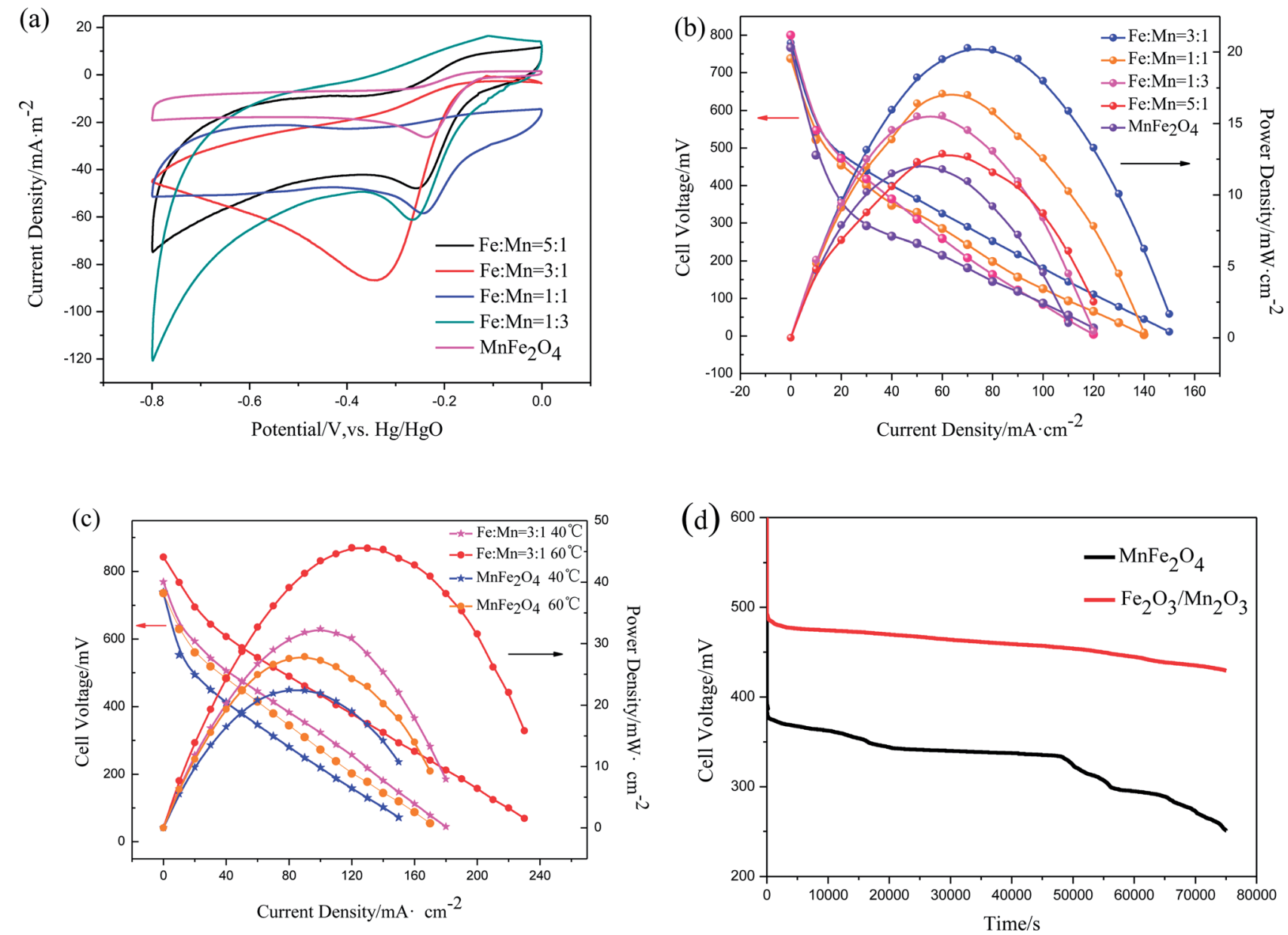

Fig. 6 (a) $\mathrm{CV}$ curves of $\mathrm{Fe}_{2} \mathrm{O}_{3} / \mathrm{Mn}_{2} \mathrm{O}_{3}$ with different Fe/Mn ratios and $\mathrm{MnFe}_{2} \mathrm{O}_{4}$ modified glassy carbon electrodes in $\mathrm{O}_{2}$-saturated $1 \mathrm{M}$ KOH solutions under ambient conditions. Scan rate: $50 \mathrm{mV} \mathrm{s}^{-1}$. Counter electrode: Pt wire. Reference electrode: $\mathrm{Hg} / \mathrm{HgO}$; (b) performance of DMFCs with $\mathrm{Fe}_{2} \mathrm{O}_{3} / \mathrm{Mn}_{2} \mathrm{O}_{3}$ with different Fe/Mn ratios and $\mathrm{MnFe}_{2} \mathrm{O}_{4}$ cathode catalysts at room temperature; (c) performance of the Fe $\mathrm{O}_{3} / \mathrm{Mn}_{2} \mathrm{O}_{3}(3: 1)$ and $\mathrm{MnFe}_{2} \mathrm{O}_{4}$-based DMFCs at $40{ }^{\circ} \mathrm{C}$ and $60{ }^{\circ} \mathrm{C}$; (d) stability tests at the constant current density of $10 \mathrm{~mA} \mathrm{~cm}^{-2}$. Fe $\mathrm{Fe}_{3} / \mathrm{Mn}_{2} \mathrm{O}_{3}(3: 1)$ and $\mathrm{MnFe}_{2} \mathrm{O}_{4}$ were employed as the cathode catalysts at room temperature. 
Table 2 Comparison of the ORR activities and DMFCs performance of the as-prepared samples

\begin{tabular}{|c|c|c|c|c|}
\hline Catalysts & $\begin{array}{l}\text { Peak current } \\
\text { density }\left(\mathrm{mA} \mathrm{m}^{-2}\right)\end{array}$ & $\begin{array}{l}\text { Peak potential } \\
\text { (V) }\end{array}$ & $\begin{array}{l}\text { BET surface } \\
\text { area }\left(\mathrm{m}^{2} \mathrm{~g}^{-1}\right)\end{array}$ & $P_{\max }\left(\mathrm{mW} \mathrm{cm}{ }^{-2}\right)$ \\
\hline $\mathrm{Fe}_{2} \mathrm{O}_{3} / \mathrm{Mn}_{2} \mathrm{O}_{3}(1: 1)$ & -58.43 & -0.246 & 12.390 & 17.09 \\
\hline $\mathrm{Fe}_{2} \mathrm{O}_{3} / \mathrm{Mn}_{2} \mathrm{O}_{3}(3: 1)$ & -86.7 & -0.348 & 21.73 & 20.29 \\
\hline $\mathrm{Fe}_{2} \mathrm{O}_{3} / \mathrm{Mn}_{2} \mathrm{O}_{3}(5: 1)$ & -47.9 & -0.257 & 18.165 & 12.88 \\
\hline $\mathrm{MnFe}_{2} \mathrm{O}_{4}$ & -26.26 & -0.237 & 3.05 & 12.15 \\
\hline
\end{tabular}

$\mathrm{Mn}_{2} \mathrm{O}_{3}$-based DMFC is superior to $\mathrm{MnFe}_{2} \mathrm{O}_{4}$-based DMFC. As shown in Table 2, $\mathrm{Fe}_{2} \mathrm{O}_{3} / \mathrm{Mn}_{2} \mathrm{O}_{3}(3: 1)$ shows the largest peak current density, BET surface area and $P_{\max }$, illustrating its superior ORR activity. Therefore, $\mathrm{Fe}_{2} \mathrm{O}_{3} / \mathrm{Mn}_{2} \mathrm{O}_{3}(3: 1)$ was assigned as $\mathrm{Fe}_{2} \mathrm{O}_{3} / \mathrm{Mn}_{2} \mathrm{O}_{3}$ and used for further studies. Fig. 6(c) shows the temperature effects on the DMFCs' performances. The $P_{\max }$ of $\mathrm{Fe}_{2} \mathrm{O}_{3} / \mathrm{Mn}_{2} \mathrm{O}_{3}$ - and $\mathrm{MnFe}_{2} \mathrm{O}_{4}$-based DMFCs are 32.4 and $22.5 \mathrm{~mW} \mathrm{~cm}{ }^{-2}$ at $40{ }^{\circ} \mathrm{C}$ and 45.6 and $27.9 \mathrm{~mW} \mathrm{~cm}^{-2}$ at $60{ }^{\circ} \mathrm{C}$, respectively. Table 3 compares the $P_{\max }$ of DMFCs in the literature. In particular, the $\mathrm{Fe}_{2} \mathrm{O}_{3} / \mathrm{Mn}_{2} \mathrm{O}_{3}$-based DMFC achieves the highest $P_{\max }$ among noble and non-noble metal cathode catalysts of DMFCs.

Stability tests were conducted in galvanostatic discharge by monitoring the voltage of $\mathrm{Fe}_{2} \mathrm{O}_{3} / \mathrm{Mn}_{2} \mathrm{O}_{3}$ - and $\mathrm{MnFe}_{2} \mathrm{O}_{4}$-based DMFCs. As shown in Fig. 6(d), at a constant current of $10 \mathrm{~mA}$ $\mathrm{cm}^{-2}$ at room temperature, the $\mathrm{Fe}_{2} \mathrm{O}_{3} / \mathrm{Mn}_{2} \mathrm{O}_{3}$-based DMFC has much higher cell voltage than $\mathrm{MnFe}_{2} \mathrm{O}_{4}$-based DMFC for $75000 \mathrm{~s}$. In about 50000 seconds, the voltage of $\mathrm{MnFe}_{2} \mathrm{O}_{4^{-}}$ based DMFC decreases sharply. For the $\mathrm{Fe}_{2} \mathrm{O}_{3} / \mathrm{Mn}_{2} \mathrm{O}_{3}$-based DMFC, no distinct attenuation phenomenon is found, indicating that this cell is quite stable.

\subsection{ORR mechanism of $\mathrm{Fe}_{2} \mathrm{O}_{3} / \mathrm{Mn}_{2} \mathrm{O}_{3}$}

In conclusion, $\mathrm{Fe}_{2} \mathrm{O}_{3} / \mathrm{Mn}_{2} \mathrm{O}_{3}(3: 1)$ exhibits higher ORR activity and superior DMFC performance than $\mathrm{MnFe}_{2} \mathrm{O}_{4}$. The first reason is that $\mathrm{Fe}_{2} \mathrm{O}_{3} / \mathrm{Mn}_{2} \mathrm{O}_{3}(3: 1)$ has a much larger specific surface area $\left(21.73 \mathrm{~m}^{2} \mathrm{~g}^{-1}\right)$ than $\mathrm{MnFe}_{2} \mathrm{O}_{4}\left(3.05 \mathrm{~m}^{2} \mathrm{~g}^{-1}\right)$, which plays a key role in enhancing ORR activity, providing numerous active sites and accelerating mass-transfer. It is worth noting that although current densities are normalized to their corresponding surface area in the CV tests, $\mathrm{Fe}_{2} \mathrm{O}_{3} / \mathrm{Mn}_{2} \mathrm{O}_{3}$ still demonstrates higher ORR activity than $\mathrm{MnFe}_{2} \mathrm{O}_{4}$.

The second reason is due to the existence of the numerous heterojunctions between $\mathrm{Fe}_{2} \mathrm{O}_{3}$ and $\mathrm{Mn}_{2} \mathrm{O}_{3}$, which provides an intensive internal electric field at the interface of the two oxides and increases the catalytic active sites, electron transfer and ORR efficiency. ${ }^{29,30}$ EIS was applied to describe the internal resistance of $\mathrm{Fe}_{2} \mathrm{O}_{3} / \mathrm{Mn}_{2} \mathrm{O}_{3}(3: 1)$ and $\mathrm{MnFe}_{2} \mathrm{O}_{4}$. As shown in Fig. 7(a), the Nyquist plots of the $\mathrm{Fe}_{2} \mathrm{O}_{3} / \mathrm{Mn}_{2} \mathrm{O}_{3}(3: 1)-$ and $\mathrm{MnFe}_{2} \mathrm{O}_{4}$-based DMFCs exhibit similar trends. The ohmic resistances $\left(R_{\mathrm{S}}\right)$ of the $\mathrm{Fe}_{2} \mathrm{O}_{3} / \mathrm{Mn}_{2} \mathrm{O}_{3}(3: 1)$ - and $\mathrm{MnFe}_{2} \mathrm{O}_{4}$-based DMFCs are $0.2 \Omega \mathrm{cm}^{-2}$ and $0.4 \Omega \mathrm{cm}^{-2}$, respectively. $R_{\mathrm{S}}$ values

Table 3 Comparison of DMFCs performance

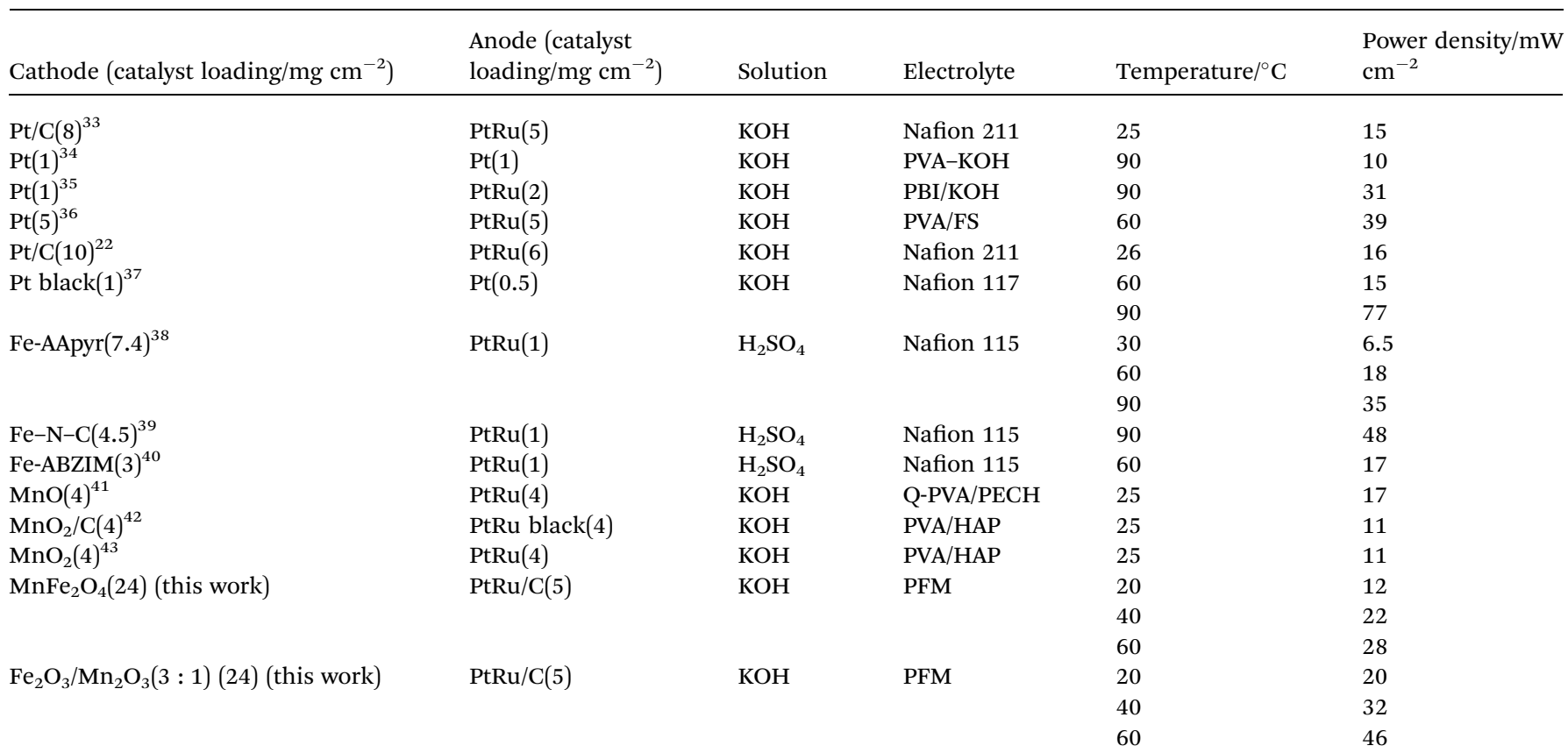


(a)

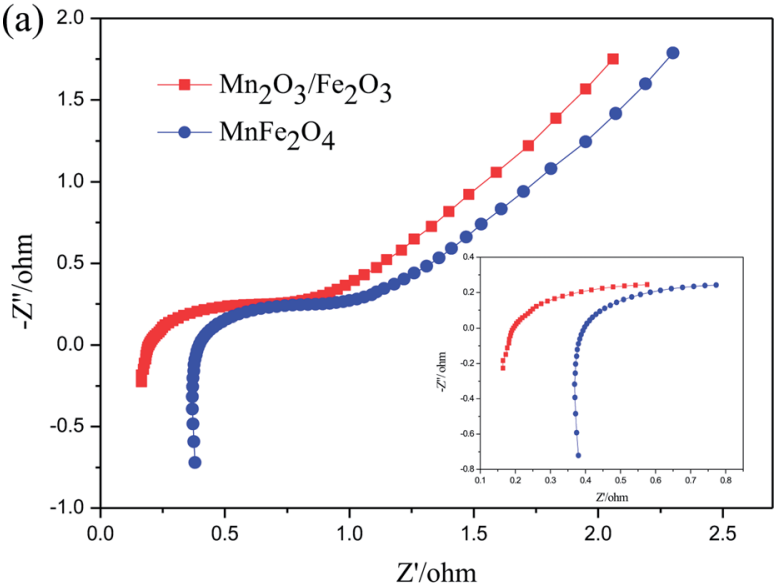

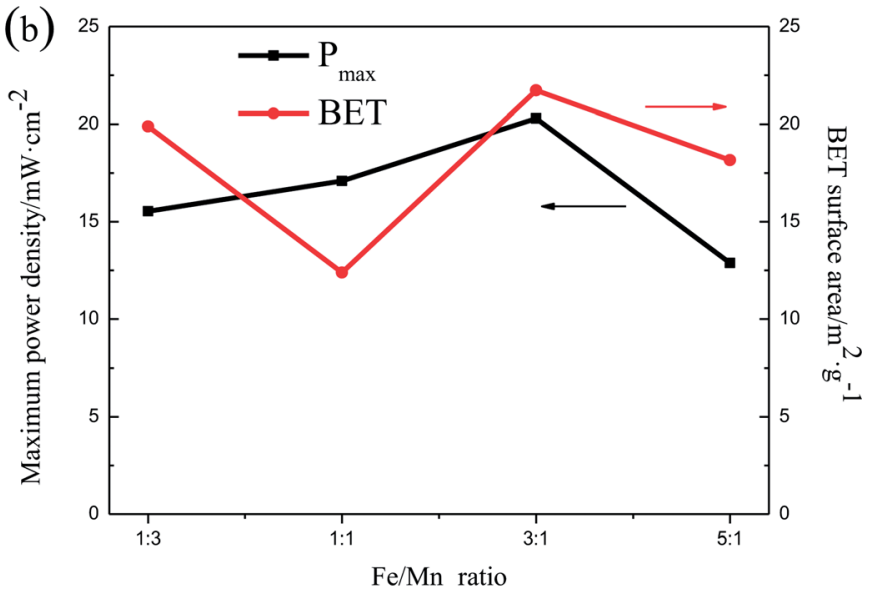

$\mathbf{O}_{2}$ $\left(\mathrm{C}_{3}\right)$

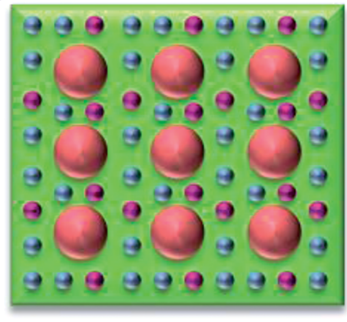

$\left(\mathrm{C}_{4}\right)$

\section{$\mathrm{HO}_{2}$}

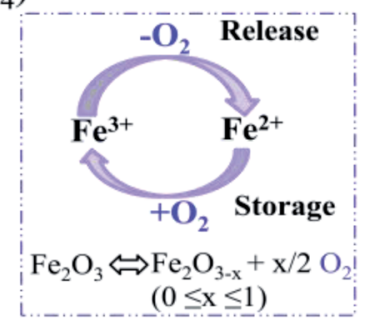

Fig. 7 (a) Nyquist plots of the DMFCs with $\mathrm{Fe}_{2} \mathrm{O}_{3} / \mathrm{Mn}_{2} \mathrm{O}_{3}$ and $\mathrm{MnFe}_{2} \mathrm{O}_{4}$ cathode catalysts. (Inset: corresponding Nyquist plot in the highfrequency range); (b) $P_{\text {max }}$ and BET surface area of $\mathrm{Fe}_{2} \mathrm{O}_{3} / \mathrm{Mn}_{2} \mathrm{O}_{3}$ with different Fe/Mn ratios; (c) schematic diagrams of ORR mechanism with $\mathrm{Fe}_{2} \mathrm{O}_{3} / \mathrm{Mn}_{2} \mathrm{O}_{3}$ as the cathode catalysts; $\left(c_{1}\right)$ the microstructure of $\mathrm{Fe}_{2} \mathrm{O}_{3} / \mathrm{Mn}_{2} \mathrm{O}_{3} ;\left(c_{2}\right)$ ORR mechanism under $\mathrm{O}_{2}$ surplus; ( $\left.c_{3}\right)$ ORR mechanism under $\mathrm{O}_{2}$ deficiency; $\left(\mathrm{c}_{4}\right)$ illustration of the $\mathrm{Fe}^{2+} / \mathrm{Fe}^{3+}$ ORR mechanism.

are the ohmic resistances of the total cell from the anode to cathode, including the solution, electrodes and membrane resistances. These two cells differ only in the cathode catalysts; they have the same solution ( $4 \mathrm{M} \mathrm{KOH}$ and $5 \mathrm{M}$ methanol), membrane and anode. Therefore, it is speculated that the lower resistance of $\mathrm{Fe}_{2} \mathrm{O}_{3} / \mathrm{Mn}_{2} \mathrm{O}_{3}$ is owing to the heterojunction providing an intensive internal electric field and increasing the electron transfer. Moreover, the content of heterojunctions between $\mathrm{Fe}_{2} \mathrm{O}_{3}$ nanoparticles and $\mathrm{Mn}_{2} \mathrm{O}_{3}$ matrix is proportional to the number of $\mathrm{Fe}_{2} \mathrm{O}_{3}$ nanoparticles. In other words, with an increase in the $\mathrm{Fe} / \mathrm{Mn}$ ratio, the density of heterojunctions gradually increases. As shown in Fig. 7(b), on increasing the quantity of heterojunctions, $P_{\max }$ is gradually improved. However, when the $\mathrm{Fe} / \mathrm{Mn}$ ratio reaches $5: 1, P_{\max }$ decreases sharply because numerous $\mathrm{Fe}_{2} \mathrm{O}_{3}$ nanoparticles wrap in the $\mathrm{Mn}_{2} \mathrm{O}_{3}$ matrix, impeding the $\mathrm{Mn}_{2} \mathrm{O}_{3}$ catalytic sites from contacting with $\mathrm{O}_{2}$ and electrolyte. In addition, $\mathrm{Fe}_{2} \mathrm{O}_{3} / \mathrm{Mn}_{2} \mathrm{O}_{3}(1: 1)$ has smaller specific surface area but higher power density than $\mathrm{Fe}_{2} \mathrm{O}_{3} / \mathrm{Mn}_{2} \mathrm{O}_{3}(1: 3)$, indicating the ORR activity follows the order of $\mathrm{Fe} / \mathrm{Mn}$ ratio instead of its specific surface area.

The third reason is the synergistic effect between $\mathrm{Fe}_{2} \mathrm{O}_{3}$ and $\mathrm{Mn}_{2} \mathrm{O}_{3}$ in $\mathrm{Fe}_{2} \mathrm{O}_{3} / \mathrm{Mn}_{2} \mathrm{O}_{3}$. The $\mathrm{Fe}_{2} \mathrm{O}_{3}$ particles not only enhance the dispersity of $\mathrm{Mn}_{2} \mathrm{O}_{3}$, but also increase the $\mathrm{O}_{2}$ storage capability. $\mathrm{Fe}_{2} \mathrm{O}_{3}$ is an n-type semiconductor with a large number of oxygen vacancies. Many reports suggest that $\mathrm{Fe}_{2} \mathrm{O}_{3}$ has the outstanding ability of reversibly exchanging $\mathrm{O}_{2}$ through the transformation of $\mathrm{Fe}^{3+}$ and $\mathrm{Fe}^{2+} \cdot{ }^{31,32}$ As shown in Fig. 7(c), $\mathrm{Fe}_{2} \mathrm{O}_{3}$ acts as an $\mathrm{O}_{2}$-storage and release site owing to the $\mathrm{Fe}^{3+} / \mathrm{Fe}^{2+}$ redox couple. It can store $\mathrm{O}_{2}$ in $\mathrm{O}_{2}$-surplus condition and release it under oxygen deficiency condition. When $\mathrm{O}_{2}$ concentration is sufficient, $\mathrm{Fe}_{2} \mathrm{O}_{3}$ captures the surrounding $\mathrm{O}_{2}$ molecules on its surface by oxidation reaction from $\mathrm{Fe}^{2+}$ to $\mathrm{Fe}^{3+}$ as shown in Fig. $7\left(c_{2}\right)$. Moreover, when $\mathrm{O}_{2}$ is insufficient, such as at high current density, the adsorbed $\mathrm{O}_{2}$ on the $\mathrm{Fe}_{2} \mathrm{O}_{3}$ surface can release and obtain electrons, thus forming $\mathrm{HO}_{2}{ }^{-}$, which rapidly transfers to adjacent catalytic sites of the $\mathrm{Mn}_{2} \mathrm{O}_{3}$ matrix via reduction reaction from $\mathrm{Fe}^{3+}$ to $\mathrm{Fe}^{2+}$ as illustrated in Fig. $7\left(\mathrm{c}_{3}\right)$. The rapid supply of excess $\mathrm{O}_{2}$ and $\mathrm{HO}_{2}{ }^{-}$can increase $\mathrm{O}_{2}$ transfer and ORR efficiency in $\mathrm{Fe}_{2} \mathrm{O}_{3} / \mathrm{Mn}_{2} \mathrm{O}_{3}$. Therefore, the synergistic coupling between $\mathrm{Fe}_{2} \mathrm{O}_{3}$ and $\mathrm{Mn}_{2} \mathrm{O}_{3}$ greatly promotes its superior ORR ability over $\mathrm{MnFe}_{2} \mathrm{O}_{4}$. However, excess $\mathrm{Fe}_{2} \mathrm{O}_{3}$ will reduce ORR ability owing to its poorer intrinsic ORR activity compared to $\mathrm{Mn}_{2} \mathrm{O}_{3}$. Above all, the larger specific surface area, large number of heterojunction interfaces, and excellent synergistic effect of $\mathrm{Fe}_{2} \mathrm{O}_{3}$ and $\mathrm{Mn}_{2} \mathrm{O}_{3}$ play key roles in the enhanced ORR activity of $\mathrm{Fe}_{2} \mathrm{O}_{3} / \mathrm{Mn}_{2} \mathrm{O}_{3}$.

\section{Conclusions}

(1) $\mathrm{Fe}_{2} \mathrm{O}_{3} / \mathrm{Mn}_{2} \mathrm{O}_{3}$ and $\mathrm{MnFe}_{2} \mathrm{O}_{4}$ were synthesized via a facile template-free solvothermal method. $\mathrm{Fe}_{2} \mathrm{O}_{3} / \mathrm{Mn}_{2} \mathrm{O}_{3}$ exists as subsize porous nanosheets-self-assembled globular structures. The 
microspheres are $3-4 \mu \mathrm{m}$ in diameter and the pore size is about $30 \mathrm{~nm}$. The formation of nanopores is due to the release of $\mathrm{CO}_{2}$, which comes from $\mathrm{MnCO}_{3}$ decomposition during the calcination process. The TEM and HRTEM images show $\mathrm{Fe}_{2} \mathrm{O}_{3}$ nanoparticles uniformly dispersed on the $\mathrm{Mn}_{2} \mathrm{O}_{3}$ substrate and a distinct heterojunction boundary between $\mathrm{Fe}_{2} \mathrm{O}_{3}$ nanoparticles and $\mathrm{Mn}_{2} \mathrm{O}_{3}$ substrate. $\mathrm{MnFe}_{2} \mathrm{O}_{4}$ has a hierarchical structure, in which the nanoparticles are 20-30 $\mathrm{nm}$ in diameter and the self-assembled globular shapes have diameters of 300$500 \mathrm{~nm}$.

(2) $\mathrm{CV}$ and DMFC performance tests show that $\mathrm{Fe}_{2} \mathrm{O}_{3}$ / $\mathrm{Mn}_{2} \mathrm{O}_{3}(3: 1)$ exhibits higher ORR activity than $\mathrm{Fe}_{2} \mathrm{O}_{3} /$ $\mathrm{Mn}_{2} \mathrm{O}_{3}(1: 1), \quad \mathrm{Fe}_{2} \mathrm{O}_{3} / \mathrm{Mn}_{2} \mathrm{O}_{3}(1: 3), \quad \mathrm{Fe}_{2} \mathrm{O}_{3} / \mathrm{Mn}_{2} \mathrm{O}_{3}(5: 1)$ and $\mathrm{MnFe}_{2} \mathrm{O}_{4}$. The $P_{\text {max }}$ of $\mathrm{Fe}_{2} \mathrm{O}_{3} / \mathrm{Mn}_{2} \mathrm{O}_{3}(3: 1)$-based DMFCs are 32.4 and $45.6 \mathrm{~mW} \mathrm{~cm} \mathrm{~cm}^{-2}$ at 40 and $60{ }^{\circ} \mathrm{C}$, respectively. The results indicated that the as-prepared $\mathrm{Fe}_{2} \mathrm{O}_{3} / \mathrm{Mn}_{2} \mathrm{O}_{3}$ catalysts achieved the highest $P_{\max }$ among noble and non-noble metal cathode catalysts of DMFCs.

(3) The much superior catalytic performance of $\mathrm{Fe}_{2} \mathrm{O}_{3} / \mathrm{Mn}_{2} \mathrm{O}_{3}$ is due to its larger surface area, the existence of numerous heterojunction interfaces and the synergistic effect between $\mathrm{Fe}_{2} \mathrm{O}_{3}$ and $\mathrm{Mn}_{2} \mathrm{O}_{3}$, which can provide numerous catalytic active sites, accelerate mass transfer, and increase ORR efficiency. It is worth noting that $\mathrm{Fe}_{2} \mathrm{O}_{3}$ acts as an $\mathrm{O}_{2}$-storage and release site owing to the $\mathrm{Fe}^{3+} / \mathrm{Fe}^{2+}$ redox couple. In addition, the synergistic effect between $\mathrm{Fe}_{2} \mathrm{O}_{3}$ and $\mathrm{Mn}_{2} \mathrm{O}_{3}$ greatly promotes its ORR properties.

\section{Conflicts of interest}

There are no conflicts to declare.

\section{Acknowledgements}

This work was supported by the National Natural Science Foundation of China $(51472153,51572158)$, the Doctoral Starting up Foundation of Shaanxi University of Science and Technology (2016BJ-75) and the Graduate Innovation Fund of Shaanxi University of Science and Technology.

\section{Notes and references}

1 J. Galindodelarosa, N. Arjona, A. Morenozuria, E. Ortizortega, M. Guerrabalcázar, J. Ledesmagarcía and

L. G. Arriaga, Biosens. Bioelectron., 2017, 92, 117.

2 X. Ren, P. Zelenay, S. Thomas, J. Davey and S. Gottesfeld, J. Power Sources, 2000, 86, 111-116.

3 L. Li and Y. Xing, J. Phys. Chem. C, 2007, 111, 2803-2808.

4 K. G. Nishanth, P. Sridhar, S. Pitchumani and A. K. Shuklab, J. Electrochem. Soc., 2011, 158, B871.

5 J. G. Liu, T. S. Zhao, R. Chen and C. W. Wong, Electrochem. Commun., 2005, 7, 288-294.

6 Y. T. Hong, H. L. Chang, H. S. Park, K. A. Min, H. J. Kim, Y. N. Sang and Y. M. Lee, J. Power Sources, 2008, 175, 724731.
7 B. Gurau, R. Viswanathan, R. Liu, T. J. Lafrenz, K. L. L. And, E. S. Smotkin, E. Reddington, A. Sapienza, B. C. C. And and T. E. Mallouk, J. Phys. Chem. B, 1998, 102, 9997-10003.

8 C. Koenigsmann and S. S. Wong, Energy Environ. Sci., 2011, 4, 1161-1176.

9 Y. Fang, X. Yang, L. Wang and Y. Liu, Electrochim. Acta, 2013, 90, 421-425.

10 X. Yang, Y. Liu, S. Li, X. Wei, L. Wang and Y. Chen, Sci. Rep., 2012, 2, 567.

11 W. Wang, D. Zheng, C. Du, Z. Zou, X. Zhang, B. Xia, H. Yang and D. L. Akins, J. Power Sources, 2007, 167, 243-249.

12 H. Yang, W. Vogel, A. Claude Lamy and N. Alonsovante, J. Phys. Chem. B, 2004, 108, 11024-11034.

13 W. Chen, J. Kim, A. Shouheng Sun and S. Chen, J. Phys. Chem. C, 2014, 112, 3891-3898.

14 G. Liu, H. Zhang and J. Hu, Electrochem. Commun., 2007, 9, 2643-2648.

15 J. Zhao, A. Sarkar and A. Manthiram, Electrochim. Acta, 2010, 55, 1756-1765.

16 M. Neergat, V. Gunasekar and R. Rahul, J. Electroanal. Chem., 2011, 658, 25-32.

17 P. Nekooi, M. Akbari and M. K. Amini, Int. J. Hydrogen Energy, 2010, 35, 6392-6398.

18 W. Yang, S. Chen and W. Lin, Int. J. Hydrogen Energy, 2012, 37, 942-945.

19 J. L. Gautier, J. Ortiz, N. Heller-Ling, G. Poillerat and P. Chartier, J. Appl. Electrochem., 1998, 28, 827-834.

20 Y. Sa, K. Kwon, J. Cheon, F. Kleitz and S. Joo, J. Mater. Chem. A, 2013, 1, 9992-10001.

21 H. Osgood, S. V. Devaguptapu, H. Xu, J. Cho and G. Wu, Nano Today, 2016, 11, 601-625.

22 Y. Liu, C. Shu, Y. Fang, Y. Chen and Y. Liu, J. Power Sources, 2017, 361.

23 Y. Fang, X. Yang, L. Wang and Y. Liu, J. Power Sources, 2014, 267, 33-38.

24 C. Si, Y. Zhang, C. Zhang, H. Gao, W. Ma, L. Lv and Z. Zhang, Electrochim. Acta, 2017, 245, 829-838.

25 V. Nikolova, P. Iliev, K. Petrov, T. Vitanov, E. Zhecheva, R. Stoyanova, I. Valov and D. Stoychev, J. Power Sources, 2008, 185, 727-733.

26 N. Hasanabadi, S. R. Ghaffarian and M. M. HasaniSadrabadi, Int. J. Hydrogen Energy, 2011, 36, 15323-15332.

27 W. Wang, J. Geng, L. Kuai, M. Li and B. Geng, Chemistry, 2016, 22, 9909.

28 C. Yuan, J. Li, L. Hou, X. Zhang, L. Shen and X. W. Lou, Adv. Funct. Mater., 2012, 22, 4592-4597.

29 L. Qiao, X. Wang, X. Sun, X. Li, Y. Zheng and D. He, Nanoscale, 2013, 5, 3037.

30 L. J. Lauhon, M. S. Gudiksen, D. Wang and C. M. Lieber, Nature, 2002, 420, 57-61.

31 L. Zhang, Y. Ni, X. Wang and G. Zhao, Talanta, 2010, 82, 196201.

32 F. G. Durán, B. P. Barbero, L. E. Cadús, C. Rojas, M. A. Centeno and J. A. Odriozola, Appl. Catal., B, 2009, 92, 194-201.

33 C. Shu, X. Yang, Y. Chen, Y. Fang, Y. Zhou and Y. Liu, RSC Adv., 2016, 6, 37012-37017. 
34 J. Fu, J. Qiao, X. Wang, J. Ma and T. Okada, Synth. Met., 2010, 160, 193-199.

35 H. Hou, G. Sun, R. He, Z. Wu and B. Sun, J. Power Sources, 2008, 182, 95-99.

36 S. J. Lue, W. T. Wang, K. P. O. Mahesh and C. C. Yang, J. Power Sources, 2010, 195, 7991-7999.

37 V. Baglio, C. D'Urso, D. Sebastián, A. Stassi and A. S. Aricò, Int. J. Hydrogen Energy, 2014, 39, 5399-5405.

38 D. Sebastián, V. Baglio, A. S. Aricò, A. Serov and P. Atanassov, Appl. Catal., B, 2016, 182, 297-305.
39 n. D. Sebastiã, A. Serov, K. Artyushkova, J. Gordon, P. Atanassov, A. S. Aricã and V. Baglio, ChemSusChem, 2016, 9, 1986-1995.

40 D. Sebastián, A. Serov, K. Artyushkova, P. Atanassov, A. S. Aricò and V. Baglio, J. Power Sources, 2016, 319, 235-246. 41 C. C. Yang, J. Appl. Electrochem., 2012, 42, 305-317.

42 C. C. Yang, C. T. Lin and S. J. Chiu, Desalination, 2008, 233, 137-146.

43 C. C. Yang, S. J. Chiu and C. T. Lin, J. Power Sources, 2008, 177, 40-49. 